\title{
Introduction: Geopolitical liquidities and nationalist trajectories: fluid boundaries and state reshaping in nineteenth-century Europe
}

Under the framework of the time-space compression characteristic of modern times, the relationship between political systems, state borders, identities and security has taken on a new appearance, particularly for the peoples living in Central and Eastern Europe and the Balkans during the arch of the twentieth century.

Such a new appearance did not affect, or did not affect in similar measure, other areas of Europe, whose geopolitical stability was not shaped in a comparable way, at least in the same period of time.

In Northern Europe, in fact, the dissolution of the monarchic personal union between Norway and Sweden, despite some bilateral tensions and the risk of a war, was in the end peacefully settled after a referendum in 1905 and a subsequent negotiation between the parties. No other consequences were perceived at the macroregional level.

However, the situation was quite different in the United Kingdom, where Irish independence was achieved in 1921 after a few years of escalating violence and then a war. The end of hostilities between the British government and the Irish insurgents led to the partition of the island, which generated further far-reaching consequences in the decades to come. Repeatedly, in fact, the coexistence of Catholic and Protestant believers, or nationalist/republicans and unionists/loyalists respectively, was threatened in Northern Ireland. Killings sporadically continued in the province from the 1920s until the conflict between the two factions acutely blew up in the 1960s. Eventually, it seems that the hostilities came to an end in 1998 when the Good Friday, or Belfast Agreement, was signed with the contribution of the US Clinton administration after two years of talks. Still, despite years of hostility and confrontations, including some recent violent revivals, the events that affected the United Kingdom and Ireland remained, to a large extent, circumscribed to these interested islands, without generating relevant effects in the rest of Europe. 
Similarly, during the Spanish Civil War, trends in support of independence were also recorded in Catalonia and the Basque Country, both of which had just achieved an autonomous status in the second Spanish Republic at the beginning of the 1930s. Nevertheless, as is well known, the fierce conflict that started between fascists and antifascists after the nationalist uprising of a group of generals in 1936 was quickly aggravated by additional international and domestic factors. These elements included, on the one hand, the military intervention of Italy and Germany in support of the insurgents, while France and Great Britain pursued a policy of neutrality. On the other hand, the USSR's relative support precipitated a violent conflict between Trotskyites, Anarchists and Stalinists particularly in Catalonia and Aragon, weakening the resistance against the Falangist (nationalist) rebels. Comprehensively, these dynamics led, ultimately, to Franco's victory and the establishment of a fascist, centralized regime. Despite all that, however, the geopolitical balance of the peninsula remained untouched and the surviving centrifugal forces were mercilessly suppressed until Franco's death in 1975.

Italy also experienced the collapse of the state during World War II, with the establishment of the Salò Republic in the North, while the Kingdom of Italy (in the South) was under the control of the Anglo-American army. Still, this partition was the consequence of the military developments on the ground and ended as soon as fascism was defeated in 1945 .

In other words, as violent as the aforementioned events have been and as brutal as the behaviors experienced by the civil populations, their impact still remained limited in terms of borders and identities. On closer scrutiny, admittedly, these events took place in the geographical peripheries of the European continent or during exceptional events, even if the British Empire was still powerfully dominating international relations.

By contrast, the dynamics that contributed to the aforementioned appearance of polity in East-Central Europe and the Balkans were (and still are) the product of extensive, diachronically pressing, and comprehensive transformations. These altered situations have affected borders, security perceptions, political systems and identities with spillover effects into a large part of the whole continent. As paradoxical as it may seem, and in contrast with its assigned "peripheral role" in terms of economic development, Central and Eastern Europe and the Balkans represented the epicenter of a European geopolitical earthquake, which occurred after the establishment of the Kingdom of Italy and the German Empire (and, to a large extent, as their direct consequence).

The largest effects of these new dynamics occurred in the twentieth century. However, they were triggered on the basis of an intense network of independent contacts and interactions across Europe as a whole, whose 
origins can be traced back to the eighteenth and nineteenth centuries, when enlightened ideas began to spread worldwide. In fact, if we consider the impact of the printing press from the 1470s together with the Reformation and the violent religious competition within Christianity, we can conclude that these dynamics developed even earlier (Bianchini 2015, pp. 6-10; Magocsi 1995, pp.48-56).

Similarly to the waves of the ocean, the radical reshaping that took place in Central, Eastern and Balkan Europe, with a pace that dramatically intensified from the second half of the nineteenth century, generated unexpected consequences in other parts of the continent. In fact, it is true that these transformations were stimulated by ideas and behaviors that began to develop mainly in the West; undeniably, however, the circularity of stimuli played a crucial role in the making of the twentieth-century nation-state dynamics of Europe. With the new millennium, the prospect of partitions is likely to shake Western Europe again, affecting the stability particularly of the United Kingdom, Spain and Belgium, with potential implication for the European Union as a whole. Meanwhile, in the East, Moldavia, Ukraine and the Caucasus remain under stress. As a result, the processes of constructing nationhood and statehood in Eastern, Central and Balkan Europe, despite individual peculiarities, cannot be disconnected from broader continental interconnections.

Geographically speaking, the main area of our scrutiny is vast, spreading from the Baltic and the Arctic Sea to the Caspian, Aegean and Adriatic Seas. Our focus is on an imaginary line running along the Elbe river down to Trieste in the South and the gorges of the Caucasus and the Urals (and even as far as the Kamchatka Peninsula) in the East.

Nevertheless, as mentioned above, it would be misleading to separate the geopolitical dynamics that have characterized such a huge space in modern times from the events, commercial exchanges, communication routes and channels, people's mobility, and cultural mainstream intersections with other parts of Europe, such as the Mediterranean, or the Scandinavian and broader Western side. This does not imply, of course, a denial of the role played by macroregional or local peculiarities, either as a legacy of specific historical experiences or because the intensity level of contacts with other environments (for instance Asia, the Caucasus and so on) notably varied from what other European areas were experiencing. Still, the interdependence of Eastern, Central and Balkan Europe from its multilateral geopolitical contexts has historically played a key role in the region's developments. This was even more relevant when time-space compression began to dramatically accelerate the speed of information, peoples' relations, and the transportation of goods (Harvey 1990).

Undeniably, time-space compression had a tremendous impact on the 
Central and Eastern European and Balkan regions. For a long time the institutional framework was distinguished by a geopolitical continuity (and stability) based on the predominant role of a few "political aggregates", which had been challenged starting from the beginning of the nineteenth century. In particular, the Habsburg (later the Austro-Hungarian or Dual Monarchy), the Ottoman, and the Tsarist Empires along with the Prussian Kingdom represented the four most relevant great, pre-modern, dynastic multinational states. These territories competitively coexisted for centuries with the oligarchic republics of Venice and Ragusa/Dubrovnik, the theocratic principality of Montenegro and the multicultural Polish-Lithuanian Commonwealth. Thus, compared with the more fragmented map of states that prevailed at that time in the West and in the Italian peninsula, a higher degree of state uniformity predominated in the East.

This "order" was even more simplified by the three partitions of the Polish-Lithuanian Commonwealth at the end of the eighteenth century, redesigned with the Napoleonic annexations and the restoration of the Congress of Vienna in 1815. Nevertheless, the new/old "order" fell rapidly into a crisis as soon as the map of Europe, once again, was radically changed by the Italian and German unifications. Since then, time-space compression in Europe as a whole began to escalate sharply, technically, geopolitically, economically and socially, shaking in particular Eastern and Central Europe and the Balkans.

The Age of the Enlightenment (or the Age of Reason) was a crucial background. It forced people to question the legitimacy of the absolute monarchies and call for radical changes in the protection of individual liberties. By spreading a cosmopolitan idea of values, the enlighteners - who mainly considered themselves philosophers - focused on the Constitution and the rule of law, on the rights of citizens and the division of powers, on public access to education and knowledge and state detachment from religious powers.

This powerful wind of reformist perspectives attracted the interest of the elites in Central and Eastern Europe to different degrees. Not surprisingly, this revealed a variety of social and cultural transformations whose achievements depended to a large extent on the way they were emphasized, perceived, and then applied. In other words, the flow of the most relevant ideals of the Age of Reason played different roles in reforming the institutions, depending on how they were designed and implemented, whether in Russia, Poland, the Grand Duchy of Lithuania (GDL), Ukraine, or in the territory of St Stephen's Crown of Hungary.

This calls attention to a very interesting aspect of European culturalhistorical interaction, which deserves closer scrutiny through comparative studies. So, for instance, enlightened reforms were to a certain extent 
considered possible and even desirable by a group of monarchs including Catherine II of Russia, Maria Teresa and Joseph II of Austria, and Frederick the Great of Prussia. Their governmental experience became known as "enlightened absolutism", a paradoxical terminology encompassing both reformism and autocracy.

Nevertheless, within this framework, distinct policies were followed. For example, Denmark was able to abolish serfdom and deeply reshape the agricultural organization of production, while the Russian Enlightenment particularly focused on changes in the sphere of education and culture to the benefit of the gentry.

Following the political inspiration of her predecessor Peter the Great, in fact, Catherine II invited a number of intellectuals (scholars, scientists, architects and artists) from all over Europe to St Petersburg. She developed a close relation with Voltaire and she established the Russian State University on Land Planning. She also expanded the role of the Russian Academy of Science (which was founded by Peter the Great in 1724 under the influence of Gottfried Leibnitz). Interestingly, during Catherine II's reign and anticipating a feminist role in the sciences, a woman, Princess Ekaterina Vorontsova-Dashkova, presided over the Academy. For fiscal reasons, secularization in State-Church relations was implemented, while an attempt to abolish serfdom was made, although it eventually failed.

Education represented the most powerful lever for reforms in Hungary as well. Joseph II's religious minority policy raised the level of literacy significantly and there was also a proliferation of the press in different native languages. Consequently, the ethnic Slovak and Romanian communities, as well as the other ethnic groups under St Stephen's Crown, took advantage of this opportunity by developing their own written literature. The national historiographies of these countries later acknowledged these events as a first step in their long path to independence.

In Prussia, Frederick the Great abolished torture, reformed the legal system, promoted rural schools and enforced more tolerance in religious matters. In particular, he stimulated culture and literature; the king himself wrote prose and poetry in French, which was, at that time, the predominant international language.

The Enlightenment was only marginally perceived in Ukraine, mainly because of its peripheral position within the existing geopolitical frameworks. At that time it was divided between Austria, Russia and the PolishLithuanian Commonwealth (the Khanate of Crimea, as an Ottoman vassal state, was absorbed by Russia in 1774). Enlightenment ideas, when they penetrated what are contemporary Ukrainian territories, stemmed from the different geopolitical contexts into which the Ukrainian space was divided. Later, this situation dramatically influenced the national 
historiography of the country, whose identity focus concentrated on the Cossacks of Zaporozhia, who were easily defeated by the Russian Empire and whose territory was separated from Poland in 1667. As a result, Ukrainian national historians are still searching for a cornerstone of their country's national identity. They are still uncertain whether to emphasize the Cossack times (which would reinforce the critical assessment of the Polish role) or to reject the existing anti-Polish stereotypes in an effort to highlight the Polish role in spreading Latin and "Western cultures" in the country. Both emphases undermine the fact that enlightenment ideas might have reached Ukraine through Russia as well (Aleksandravičius 2014, pp. 257-76). ${ }^{1}$

The situation of Belarus, which was incorporated for centuries within the Grand Duchy of Lithuania, was also unique. Innovative education policies substantially affected the GDL, particularly due to the role played by the University of Vilnius. Established in 1579 by Stefan Batory and led by the Jesuits for several centuries, this institution became a crucial lever for the dissemination of enlightened ideas in the second half of the eighteenth century together with new educational programs and the printing press publications in Lithuanian and Polish languages in Vilnius, Kaunas, Kedainiai and Vevis.

Although Polish was the favorite language for Belarusians where printshops began to operate from the sixteenth century, there was also some room for printing in the Ruthenian-Belarusian languages. In this context the nobility played a predominant role. They absorbed enlightened ideas from Jesuit colleges (most of them in Poland and Lithuania) or Orthodox schools and academies (in Eastern Poland/Ukraine and GDL), with a significant impact on the arts, theater, architecture and music (Glemža 2014, pp. 99-117).

In short, the development of the humanities was one of the most relevant aftermaths of the dissemination of enlightened ideals in Eastern Europe.

This was also true for the Balkans under the Ottoman Empire. Education, language reform, debates and secularization were the most relevant features to penetrate deeply into South-East Europe during the eighteenth century. Initially, printing houses spread particularly among the Christian and Jewish communities rather than among the Muslim

1 This is an excellent example of the impact on historiography of the politics of memory and conflicting narratives. In the euphoria of freedom, after the collapse of Communism, "objective" investigations of the past occurred without the constraints of the previous ideological indoctrination. Soon thereafter, however, objectivity vanished when a national unique "true history" appeared in the textbooks under governmental control. This also created a dysfunctional relationship between "academic and popular discourses". 
Ottomans. However, after 1727 when the first Turkish print shops opened in Kostantiniyye/Constantinople (today Istanbul) this crucially relevant innovation affected the empire as a whole (Bianchini 2015, pp.6-7). As a result, cultural initiatives multiplied particularly in the second half of the century. Book contents and the gradually more sophisticated political discourses of the Balkan intellectuals showed increasing detachment from religious interference. The debate over language reforms was another key aspect of the dissemination of the Enlightenment, given the extremely high variety of vernacular variants spoken by the peasantry. The issue long remained a central concern for Greek literature, Serbian cultural circles, the so-called "Transylvanian School", and Bulgarian activists committed to promoting an accessible literary language.

Secularization, in turn, began to expand thanks to the travelers, merchants and sailors who described in their portolan charts and handbooks a new symbolic geography. Their reports replaced those of pilgrims and religious representations with accounts about the modernity inputs and the social and economic transformations they observed during their trips in Europe or around the world (Daskalov 2004, pp. 35-8; Jelavich 1983, vol.1, pp. 171-2; Kitromilides 2006, pp.47-50; Wolff 1994, pp. 17-49).

These aspects strengthened nationalist aspirations in the decades to come. Popular (rather than the divine) legitimacy of power was established, political equality was stressed in terms of equal access to certain rights, and mass education was introduced. This was a shared process that affected Europe as a whole. Thereafter, schools taught humanities, in particular, in a way that encouraged a collective sense of identity and a loyalty to the state, through a "national interpretation" of history, literature, language and the arts. The process gradually developed during the nineteenth century, but the first steps were taken already during the Enlightenment and accelerated later, under the influence of the romantic reaction against the enlighteners, as we will see below.

Crucial in this respect is how the new dynamics evolved in the PolishLithuanian Commonwealth. The dominant language increasingly became Polish, despite the fact that six languages were officially in use including Latin, German, Hebrew, Ruthenian and Armenian, but surprisingly not Lithuanian. In fact, even though (1) equal rights were recognized for the two components of the state; (2) the origin of the Jagiellonian dynasty was Lithuanian (with the wedding of Grand Duke Jogaila with the Polish Queen Jadwiga in 1386); and (3) some kings after the Union of Lublin in 1569 were Lithuanian by origin, the Polish nobility quickly assumed a leading role in state affairs.

Consequently, in the modern process of national construction of both Poland and Lithuania, Lithuanian historians critically considered these 
events to be disturbing effects of the enlightening educational process. They were viewed in fact as vectors, not only of democratic values, as mentioned above, but also of centralization and unification, which strengthened in the long run the regional "polonization" of the aristocracy to the detriment of Lithuanian-ness.

The nexus between the Enlightenment and centralization is very important. As is known, the Age of Reason was to a large extent (but not exclusively) generated in France between the seventeenth and the eighteenth centuries, precisely when the centralization of powers was resolutely carried out by the absolute monarchies of the so-called ancien régime, particularly during the reign of Louis XIV. Actually, the centralization was part of the process of state and imperial consolidation once the dichotomy between the Papacy and the Empire was abolished. These principals of sovereignty and non-interference in state affairs were proclaimed by the Peace of Westphalia in 1648.

Therefore, these two aspects, that is state centralization and the assertion of the cosmopolitan ideals of constitutional law and individual rights, were generated by two different processes and originally stemmed from alternative political projects. Nonetheless, educational expansion as a product of the Enlightenment, followed later by language standardization (as an identity process of collective self-recognition), powerfully intensified as the French revolution exported its ideals Europe wide. At the same time, administrative centralization was seen by the revolutionary leadership in Paris not so much as a legacy of the ancien régime, but as a useful means for granting effectiveness to institutional functionality. This approach explains to a large extent why the Enlightenment, unification and centralization were not necessarily understood as conflicting factors, but, rather, as useful vectors able to guarantee both individual rights and the freedom of peoples.

There was another consequence, however. The emphasis given to the interaction of education and centralization crucially contributed to the enhancement of the equivocal relationship between nationhood, demography and geopolitics whenever the reshaping of state was addressed. The imagined process of national unification was, in fact, fully encoded in the revolutionary projects of the anti-restoration movements after 1815. Consistently, centralization and unification were included in their programs as achievements to be implemented as soon as the "tyrannies" imposed by the Congress of Vienna were eradicated with the "triumph of national independence".

At the same time, however, these enthusiastic aspirations nurtured the seed of new conflicts. The geographical and ethno-cultural space of the potential nations was, and remained, undetermined and extremely volatile, 
depending on the fluctuating interpretations of what a nation was and where the borders were. Eventually, they generated opposing national projects, if not doctrines. In fact, enlighteners emphasized cosmopolitanism and individual rights; some of them also came to the conclusion that a natural law existed and endowed individuals with a number of "inalienable rights", which would have been guaranteed by a constitution. In their view, the enjoyment of these freedoms was connected to associations (that is, the states) where free individuals were bound by a sort of social contract. Within this framework, nevertheless, centralization and unification led to opposite interpretations and results. On the one hand, as already noted, they were understood as effective tools for the functioning of public administration and the creation of a shared sense of belonging. On the other hand, they suggested a trajectory towards an ethno-cultural homogenization that centered on, not the individuals, but the collectivity, whose intrinsic varieties were rejected and recognized as a threat to group amalgamation.

Already in the eighteenth century, individuality was questioned by influential scholars. For instance, Johann Gottfried Herder focused his critique of the cosmopolitanism of the Enlightenment by stressing the "uniqueness of the national culture" in his philosophy of history, insisting on the collective right of the nation to protect its own traditions, its historical memory, its poetry and language (Herder 1765-97 [2002], pp. 59-64 and 272-9).

Although Herder never connected the idea of nation to the concept of state, he expressly rejected the supremacy of French culture, drawing attention to the development of the main national strands that were not inspired by France. In particular, according to his view, three main phases characterized the history of the "suppressed nations". An initial "Golden Age" that he approximately identified with the European Middle Ages period was followed by a period of oppression of the national identities under the great Empires or other predominant states. Finally, he envisioned an achievement of an "awakening status" which would lead to the establishment of a modern and free nation, accomplishing the "divine goal" in the history of humanity (or, in other words, "leading to the end of history").

These ideas, nurtured by an anti-enlightenment romantic mainstream, successfully expanded in East-Central Europe and in the Balkans, together with an anti-French strand that affected the former rather more than the latter. In fact, the Napoleonic military campaigns mainly influenced the Italian peninsula and Central Europe (before the invasion of Russia in 1812). They only marginally affected the Balkans, although they did put an end to the patrician Republics of Venice and Dubrovnik, while creating the Illyrian provinces. This was locally viewed as the first political attempt to 
unify the South Slavs, by generating the movement initially called Illyrism, and later Yugoslavism.

By contrast, the campaigns in Central Europe encouraged Johann Gottlieb Fichte to severely criticize revolutionary France and its "progressive mission" throughout the continent. In his famous addresses to the German nation, he denied the relevance of civilization, if introduced through military occupation and annexation, as the Roman Empire did in the ancient era. Radically, Fichte suggested that backwardness is preferable to social and civil progress, if it threatens the freedom of people. He also emphasized the positive role of bias and stereotypes that clearly define the borders between groups (or, in modern terms, the distinction between "us" and "them"). He unequivocally ascribed a "supreme, final, absolute authority" to the love of fatherland, even to the detriment of the "natural freedom of individuals" that "must" be, consequently, limited "in many ways". 2

It was under these circumstances, when the French Revolution was militarily expanding his values and most of the ideas of the enlightened philosophers together with the Napoleonic Code, ${ }^{3}$ that centralization and unification were also "exported" Europe wide, as part of the French experience.

This legacy of the period of absolute monarchy merged, paradoxically, with the concept of divine legitimacy of the rulers questioned by enlightened philosophers as well as the French Revolution, which replaced it with the "will of the people", on behalf of the French nation.

As a result, a very intricate situation marked the impact of the Enlightenment on Eastern Europe. The ideals of the great thinkers of the eighteenth century were "re-elaborated" by giving relevance (and, to a certain extent, also priority) to the perspective of unification and centralization. This, in turn, provided substance to the collective rights of the national culture and identities, rather than endorsing individual rights.

Moreover, it was difficult to determine the "will of the people" for the simple reason that the "people" were composed of a large variety of intercultural and multifaceted groups of individuals, living in vast territories. This was particularly evident in Eastern Europe where few states, as mentioned above, had clear geopolitical borders. Within this

2 Johann Gottlieb Fichte, Addresses to the German Nation, translated by R.F. Jones and G.H. Turnbull, Chicago: the Open Court Publishing Co., [1808] 1922, especially the Eighth Address, pp.138-42. The full text of the addresses is also available at https:/archive.org/ details/addressestothege00fichuoft (accessed 10 December 2016).

3 Napoleon was not the first leader to elaborate a Code. A Civil and Criminal Code had in fact already been introduced in Russia by Catherine II. 
context, the emphasis of French revolutionaries on language (even if its knowledge was very approximate, because of the high level of illiteracy) as well as on the centralization and unification of the state, viewed as an effective administrative apparatus, significantly influenced the perception of the Enlightenment ideas and the quality of the necessary institutional, economic and social reforms in Eastern Europe.

The dissemination of these ideas, in effect, soon became a bone of contention in the vast territory of the Polish-Lithuanian Commonwealth. The weakness of the Commonwealth dated back to the beginning of the eighteenth century, when the Russian Tsar Peter the Great began to play an influential role in the region. The existence of the "dual state" was increasingly threatened, particularly from the 1770s; it ceased to exist in 1795. The predominant role of the Polish language in the Commonwealth was, in fact, a matter of discontent among Lithuanians. However, they also detested the claims to centralization and unification that were inspired by the enlightened ideals, but that clashed with the existing autonomies. In addition, state governance suffered from a set of other dysfunctional features, among them the liberum veto (the right of veto granted to any individual deputy).

A first reform attempt promoted by King Stanisław II August Poniatowski was rejected by those nobles who wished to protect their privileges and opposed the increasingly influential role of Russia. The initial success, by military means, of these nobles actually enabled the neighboring powers to intervene and created the first Commonwealth partition. Still a new wave of reforms to modernize the state and increase its effectiveness was designed and discussed after the 1772 partition, particularly during the Four Year Diet (1788-92). However, the content of the reforms severely divided the gentry, in particular when a constitutional draft was debated, and later passed, by the Parliament (the Sejm) on 3 May 1791.

Influenced by the French and American Revolutions, the Constitution established the separation of the executive, legislative and judicial powers, a Council of Ministers, and the supremacy of the Catholic Church. However, the most controversial point concerned the reinforcement of centralization and unification. In effect, the GDL lost its judicial, financial and military authority. Furthermore, a hereditary monarchy was installed together with the introduction of majority voting in the Parliament and the abolition of the liberum veto. Gentry confederations were banned and the right to vote was strictly connected to property credentials, which expanded the potential voters by including the bourgeoisie.

Nevertheless, a conservative gentry military confederation, based in South-East Poland, which radically opposed the Constitution, made contacts with tsarist Russia. Since 1717, Russia had gradually established 
a protectorate over the Polish-Lithuanian state, when, influencing the socalled Silent Sejm, it was able to drastically reduce the size of its military force. Thus, Russia feared the regional implications of the reform. In the end, Catherine II with the support of the Kingdom of Prussia intervened and imposed a second partition in 1793. Russia annexed a large part of Eastern Lithuania, Belarus with Minsk and Ukraine up to Podolia; Prussia obtained a region close to Gdańsk (Danzig) and some Western areas of Poland re-named "Southern Prussia". The failure of Tadeusz Kościuszko's uprising one year later led to the third partition, with the participation of Austria, and put an end to the Commonwealth forever.

Crucially, these events marked the first important example of state partition in modern times.

Their relevance, in fact, lies in the chronology. They occurred in a transitional historical phase, when pre-modern institutional frameworks were rapidly declining, as was the role of the aristocracy, either within absolute monarchies or as patrician oligarchies or "a republic of nobles". Simultaneously, the process of construction of the nation-state was just beginning to develop.

However, the transition to the national form of state was never linear, nor was it unambiguous.

The very idea of the nation-state was questioned and interpreted in dissimilar and competing ways in politics and literature. In the case of the events that followed the suppression of the Polish-Lithuanian Commonwealth, the national inspirations nurtured in the nineteenth and twentieth centuries by their local elites (and later by their national historiography) diverged. In some places, they galvanized young activists to attempt to achieve the freedom of "suppressed peoples" from empires or from foreign occupation, while associating the enlightened ideals with territory and history. However, elsewhere, the association led to opposite conclusions; in fact, it was alternatively connected to the memory of the Commonwealth (in Poland) or to the Grand Duchy (in Lithuania), paving the way for far-reaching consequences when new historical conditions would offer the opportunity for (re)establishing the independence of these territories.

In any case, language was a powerful lever for defining group identity, although the definition of language in itself was (and still is) a controversial issue. Basically the aristocracy and most of the intellectuals were speaking and writing in French, which was also the diplomatic language of the time. The French Revolution, and later the military campaigns of Napoleon, led to territorial adjustments and annexations to the benefit of the new empire. However, they also generated the contradictory aftermath of spreading the ideal of liberty among peoples (against the monarchs), 
together with a basic use of French, which was often rejected (particularly by romantic leaders inspired by Herder) as an expression of cultural supremacy. The predominant role of French, in fact, seemed to contradict the revolutionary goals of égalité (equality) and fraternité (brotherhood). Instead, writers and philosophers realized that it was morally relevant to develop standardized local literature in order to meet the third revolutionary goal of liberté (liberty).

On the other hand, ordinary people, to a large extent illiterate, preferred to speak in the vernacular. Also, the gradual expansion of the Industrial Revolution increasingly required that rural workers understood what to do in the factory and how to work with the machines. In other words, workers needed to be educated. As a result, the combination of both economic requirements and the aspiration of affirming a national identity (as an alternative to the divine legitimacy of powers) contributed to making the question of the standardization of the languages a matter of immediate importance.

Initially, the construction of national languages and literature within the great European Empires was fostered by both students and intellectuals, according to the contexts and the periods. This was the case with Latvian students at Dorpat University, of the Society of the Estonian Literati, or the cultural associations of Lithuanians and Latvians in the University of St Petersburg. In the Balkans a number of reading rooms were established in order to teach the language and to collect anthropological reports about the oral culture of the peasantry, including poems, folk songs and cooking recipes (Mole 2012, p. 34; Salvi 1971, pp. 83-7).

These dynamics were carried out by thinkers and young political activists who often unconsciously merged cosmopolitan enlightened ideals with romantic visions of the nation. They impatiently worked to free Europe as a whole from the "chains of the tyrants", identified with the old monarchies, as soon as the Congress of Vienna restored that "old order" after the Napoleonic defeat at Waterloo.

Admittedly, the rationalist and individualist approach propagated by the enlighteners was culturally challenged by the development of Romanticism and its interest in nature. These aspects soon became very attractive in the wider European context. As is well known, Jean Jacques Rousseau focused on the uniqueness of the human being and suggested that the only way to rebuild civilization was to make its principles consistent with the "authentic nature" of humanity. As a result, a new wave of thinkers began to investigate the relation between nature, popular culture (mostly oral and written literature, arts and history), the role of the peasantry (as the key representative of the "people") and folklore, including mythology. This effort had a crucial impact in liberating the imagination in political-cultural terms 
by spreading the belief that the human being is part of a broader natural order, far beyond brotherhood and solidarity. Rooting this approach in the awareness of the population led to the development of a new morality, in which emotions play a key role in contrast to the "pure rationality" emphasized by Emmanuel Kant.

The claim that emotions matter in a "natural society" created a dual effect. On the one hand it contributed to the intensification of philanthropy and social reforms against discrimination (from child labor exploitation to the abolition of the slave trade). However, on the other hand, it encouraged national ideas, especially the development of an exclusive patriotism, whose sentiments were intended to prevail over individual feelings, as Fichte was advocating. This approach was later embraced by governments, especially from the second half of the nineteenth century, which vocally identified the love of nation with a passionate (and supreme) sense of belonging. Therefore, they promoted the identification of the group with a constructed "natural" cultural homogenization, common blood and spiritual life, sharp distinctions between "us and them", and a powerful sense of the historical continuity of popular traditions (once again identified with a "natural development") and people's self-recognition (Antoni 1942; Breuilly 1993; Chabod 1962; Plumyène 1979; Smith 1986; Viroli 1995).

At first, however, Enlightened rationalism and Romantic spiritualism were not necessarily always viewed as incompatible, although the latter was an intellectual and artistic reaction to the former. On the contrary, their boundaries remained often fluid, generating an intricate (and sometimes contradictory) series of feelings, expectations and behaviors that influenced, in different ways, activists and conspirators from different countries.

It was under these circumstances, and despite the apparent retreat of independence aspirations in 1815, that a revolutionary ethos was spiritually rooted in the young generations. They joined secret organizations and began to plot against the re-established empires or monarchies, which they viewed as oppressive. This ethos, originally based on the idea of freedom for all nations, empathized with the suffering of the "oppressed peoples" and expressed a broad sense of solidarity with them. These sentiments were nurtured across the whole continent and empowered by the increasing relevance accorded to social and cultural rights.

Key leading roles were initially played by the Polish/Lithuanian aristocrat Adam Jerzy Czartoryski (or Adomas Jurgis Čartoriskis), the Italian philosopher and activist Giuseppe Mazzini, and the Hungarian noble Lajos Kossuth ${ }^{4}$.

4 Actually he emerged from a poor gentry family. 
Czartoryski, born in Warsaw, was a close friend of Tsar Alexander I and served in the Russian diplomatic corps. He made a crucial contribution in the design of the Constitution of the Kingdom of Poland - one of the most liberal for the time - when the Congress of Vienna attached the country to the Russian Empire in personal union with the tsar.

Yet, under the new tsar, Nicholas I, he became the leader of the Polish uprising in 1830 and joined the troops of Italian General Girolamo Ramorino, who was fighting in support of Poland in the Krakow region. When the rebellion was crushed by the Russian army, Czartoryski went into exile in France and established his headquarters in the Hôtel Lambert in Paris. This became a nerve center for European revolutionaries interested in overthrowing the order established by the Congress of Vienna. This historical period was extremely important because plenty of revolutionary projects were designed, while political activists from all over Europe were meeting in France, a country still considered the homeland of the revolution.

Czartoryski himself supported the idea of the restoration of the PolishLithuanian Commonwealth as a federation, by including Czech regions. Furthermore, he elaborated plans for a Romanian-Hungarian-Yugoslav union. In this context he also suggested that the Serbian Minister of the Interior, Ilija Garašanin, prepare a strategy for unifying the South Slavs of the Bosnian, Croatian and Slovenian lands with Serbia by detaching them from the Habsburg Empire. In this way he hoped to create the conditions for launching a new Polish uprising in the North, while forcing Austria to fight a two-front war. Prospectively, he did not even exclude the foundation of a greater federation from the Baltic Sea to Serbia, including Hungary and Romania.

These plans cannot be considered mere dreams. Rather, they reveal a deep concern with how to merge the intercultural reality of East European societies with the nationality program of freedom of peoples. At the same time revolutionary activists were meeting in particular in France and Switzerland in order to investigate how to implement their plans.

Giuseppe Mazzini was another great revolutionary instigator, not only with his actions against the Kingdom of Sardinia, Austria and the Papacy in support of a republican unification of Italy, but also with his thoughts. He directly connected the promotion of Italian unification (through his secret organization "Young Italy") with a broader project, the overthrowing of the European settlement of 1815 and the establishment of a popular convergence of free nations into a loosely federalized Europe. In 1834 in furtherance of this cause, he founded in Berne another secret organization, "Young Europe". He considered that the unification of Italy would be just a preliminary act in the broader plan, which would include the 
establishment of a European assembly that would harmonize the common interests of the European peoples (Gangulee 2014; Mazzini 1945).

His revolutionary ideas never excluded the use of violence against the "tyrants". In fact, he promoted several riots, since he imagined the use of violence as a means to organize conspirators in order to promote a general, popular rebellion. Neither did he exclude the option of "tyrannicide", according to a long-term Italian tradition, which dates back to Saint Thomas of Aquinas, Vittorio Alfieri and the Carbonari secret society. Historically, after all, the assassination of "Tyrants" was celebrated in ancient Greek and Latin philosophy and literature, from Plato to Aristotle, from Cicero to Tacitus. Its legitimacy was frequently justified by Christian theologians in the Middle Ages, by John Milton during the English Civil War, by John Locke, and by Friedrich Schiller in his romantic works. Therefore, it is not a surprise that even Mazzini included the "morality of tyrannicide" among the means to be taken against a brutal oppressor.

His authoritative view influenced a number of militants, who believed that the killing of the symbols of the old Power (and particularly of kings and emperors) was legitimate and would accelerate the revolutionary process. Felice Orsini, who failed to assassinate Napoleon III in 1858, was a member of Mazzini's secret organization. His plot against the French Emperor enjoyed his master's praise. Inspired by such a revolutionary morality (deeply felt by the conspirators), the actions against "tyrannies" - or terrorist attacks, according to the interpretation of the established powers - quickly became popular throughout Europe, especially in Italy, as well as in Hungary, Russia and the Balkans in the decades to come (Jászi and Lewis 1957, p. 123; Mazzini 1929, pp.156-7).

Mazzini, moreover, played an influential role from an organizational point of view. His secret societies inspired, as a model, other European activists, who established such groups as "Young Germany", "Young Poland", and later also "Young Bosnia", "Young Latvians" and "Young Turks". Mazzini was also an opponent of the Enlightenment idea of individual rights, believing that individual achievements should be the outcome of hard work and sacrifice, which was consistent with his idea of a civic religion. In this sense, he spent all of his life affirming the religiosity of duty, seen as a moral action in a cultural ethos that rejected individualism, while promoting the love for the fatherland as a divine mission (Viroli 1995).

In this context he took into consideration the convergence of purposes among Italians, Polish, Hungarians and Slavs. Later, analyzing the role of Russia and its Panslavism in his article entitled "Politica Internazionale" (International Politics), he concluded that a 
federation of Polish-Lithuanians and Czechs in the North together with a Danubian-Balkan association of peoples in the South was a desirable solution, which would establish a solid barrier between Russia and Northern Germany. ${ }^{5}$

In the end, although his projects failed during his lifetime, his ideas proliferated and inflamed the imagination of a number of European national activists for at least a century (Dedijer 1966, pp. 201-16).

A third relevant nationalist personality was Lajos Kossuth. He was controversial in a different way from Czartoryski and Mazzini. Nevertheless, he symbolically epitomized the conflicting characteristics of nationalism. Kossuth, a lawyer and journalist, became popular in Hungary when he demanded freedom of the press and speech throughout the Habsburg Empire. He was subsequently arrested. Following liberal ideas and the French national model of centralization and unification, he extended the notion of "Hungarian-ness" to all peoples living in the territory of St Stephen's Crown, irrespective of their ethnic origin.

Similarly, he believed that only one language (Hungarian) should be officially used in a state. His opponent, Count István Széchenyi, warned that his policy would have had the effect of setting the nationalities against each other, as actually happened during the Hungarian revolution in 1848-49.

Indeed, the development of the events of 1848 in the Habsburg Empire followed divergent patterns. The Prague Slavic Congress that took place in June was primarily a reaction to the German National Assembly in Frankfurt and a meeting against German nationalism. Dominated numerically by Czechs and Slovaks, but with the participation of both the South Slavs and the Polish-Lithuanian-Ukrainian representatives, the Prague Congress issued a Manifesto to the Nations of Europe in support of the preservation of the Austrian monarchy and its transformation into a federation of equal peoples.

By contrast, the radical Hungarian intellectuals promoted a public protest against censorship, then claimed an autonomous government. When the supporters of a parliamentary monarchy within the Austrian Empire resigned, they declared an independent republic. Among these intellectuals was the poet Sandor Petöfi, who was later elevated to the pantheon of national heroes and was considered the master of Hungarian poetry. Incidentally, as a confirmation of the identity fluidity of Central Europe, his family name was actually Petrović or Petrovics, because his father was a Serb and his mother a Slovak.

5 Giuseppe Mazzini, "Politica Internazionale", in La Roma del Popolo, n. 4, 5, 6, 1871, pp. 144-8, currently at https://bibliotecairredentista.files.wordpress.com/2014/02/giuseppemazzini-politica-internazionale-1871.pdf (accessed 12 December 2016). 
In this context, and in contrast with his previous convictions, Kossuth whose policy anyhow appealed only to the aristocracy - actively supported a law on minority rights. This law recognized the use of the mother tongue in the administration, the tribunals, the schools and councils only for the Romanians and Croats, but not the Slovaks, since he denied the existence of the latter's nationality. This act, however, was not enough to attract the loyalty either of the Croatian Ban Jelačić, who militarily supported the Habsburgs, or of the Romanians of Transylvania, or part of the Serbs. In the end, as is known, the tsar sent the Russian army to Hungary in support of Austria and put down the revolution on behalf of the principles of the Holy Alliance.

After this experience, Kossuth moved to Turkey, then to London and Italy. During his exile in Kütahya, he reconsidered his political experience. He concluded that only a federation of peoples could have avoided this new revolutionary failure in Central Europe.

In a sense, he recognized that empathy matters (Rifkin 2012, pp. 333-5). Still, he remained uncertain about the extent to which this federation could have been carried out. Initially, inspiring a memorandum of the Hungarian émigrés in 1851, he limited his vision to cooperation on economic and individual rights in the Danubian basin. Later, he elaborated an idea of a union of some of the peoples of the Habsburg Empire (including the Czechs, Croats, Romanians and Poles, together with the Hungarians). When he came to the conclusion that the Ottoman Empire was too weak to survive, he focused southward, considering the possibility of a union among the Serbs, Romanians and Croats, and possibly with BosniaHerzegovina and Montenegro.

Again, all these projects were not just the outcome of political illusions. On the contrary, after the crackdown on the Hungarian Revolution, a number of revolutionary thinkers and activists began to realize that nationalist ideas might not lead to freedom in Europe, but to new policies of assimilation or conflicts between ethnic groups, with the unexpected result of reinforcing the power of "tyrannies". This concern was shared by other revolutionary personalities, like the Romanian Nicolae Bălcescu. He participated in a conspiracy against a Romanian prince in the Paris uprising in 1848, and then, in Bucharest, in an attempt to negotiate a deal with Kossuth. Later, he was arrested by the Ottomans. In 1850, Bălcescu proposed in London a federal project of the Danubian basin, including Moldavia, Wallachia, Bessarabia, Bukovina, Serbia and Hungary. In his view, Latin would have been the common language, in consideration of the fact that Latin was still in use in the Hungarian administration.

The individual story of these personalities was basically similar, as they were all well educated and mostly of aristocratic or bourgeois origins. The 
revolutionary ideas they nurtured since their early years were enthusiastically elaborated and then transformed into fierce and passionate beliefs. As a result, they took part in all of the European uprisings, whenever they occurred, with the hope that any riot would trigger a sort of "transmission chain" that would mobilize other people to achieve freedom across Europe and, therefore, for the benefit of their homeland as well. In this sense, a revolutionary empathy still marked the relations of nationalist activists and leaders.

This widespread mindset explains why they were so mobile, visiting numerous countries, from Constantinople to London, from St Petersburg to Paris. They met regularly, jointly conspired, and were repeatedly arrested, jailed, sentenced to death, or forced into exile. During their adventurous lives, they had the chance to discuss their views about democracy, freedom and nationalism, as well as the role of religion, individual and collective rights, the future of suffrage, literature, arts and the social and economic aspects of the various European societies.

Despite their personal convictions, liberal, socialist or anarchist, their revolutionary aspirations and the repressions they often suffered created a unique (and mobile) environment that generated a sort of a transnational, European "intelligentsia". In their own, mostly illegal circles, they had the chance to compare and assess their visions with other great personalities of the time, like Mikhail Bakunin, Pëtr Kropotkin, the Russian Narodniks (especially Nikolai Chernyshevsky, who suggested the foundation of a Danubian federation from Bratislava to the Black Sea), Karl Marx and Tomáš Masaryk. Thus, they developed a sense of solidarity, based on the ethic of freedom for all.

As utopian as it may appear, a particular personality powerfully embodied this ethic. This personality was the Italian Giuseppe Garibaldi. His participation in wars for independence in Latin America (Rio Grande do Sul and Uruguay) and then in the Italian peninsula attracted the enthusiasm of many volunteers (mainly students and artisans), who joined his popular armies of "red shirts". Among them was István Türr, as well as other Hungarian or Polish revolutionaries. Garibaldi's extraordinary enterprises impassioned the young activists of a number of secret societies. For example, he defended the Republic of Rome against the papal troops, but he also organized the "Expedition of the Thousand", giving the Kingdom of the "Two Sicilies" to the King of Piedmont in 1860. Because he was wounded in Aspromonte in 1862 and temporarily imprisoned, Garibaldi was unable to participate in the American Civil War. However, he was in contact with Lincoln, encouraging him to declare publicly that the emancipation of slaves was the primary goal of the war. In February 1863, although suffering from a physical disability, he launched the appeal "To the peoples of Europe" in support of the Polish uprising. 
Furthermore, his romantic ideal of fighting for the freedom of every nation persuaded him to take an active part in the war in support of the third French Republic after Napoleon III's defeat at Sédan. Garibaldi did so despite the fact that a few years earlier (in 1867) he was defeated by the French Army, which defended the Papal State when he wanted to annex Rome to the newly established Kingdom of Italy.

The inflammatory ethos that Garibaldi was able to transmit throughout Europe had a relevant impact also in the Balkans. Yugoslavism, as a legacy of the Illyrian ideals of the first decades of the century, was attracting growing support among young people, and the "red shirts" took part in the Bosnian uprising in 1875.

It was within this passionate cultural framework that, already in 1853 , a Croatian journalist and policy maker, Imbro Tkalac, stressed the central role of the Serbs in the South Slav context. In the 1860s, two Catholic bishops, Franjo Rački and Juraj Strossmayer, emphasized the Yugoslav ideal for the unification of the Slavs in South-East Europe. Within this perspective, Strossmayer founded the Yugoslav Academy of Sciences and then the University of Zagreb. Later, he also agreed with the Minister of Foreign Affairs of Serbia, Ilija Garašanin, about the need to create a Yugoslav State between Austria and Turkey, using as a model the Italian and German unifications that were successfully achieved in those years.

In Italy, by the way, not only Garibaldi, but also Mazzini and Tommaseo, expressed publicly their view in support of the "liberation of the South Slav peoples". Even the Prime Minister of the Kingdom of Sardinia Cavour in the early 1860s had explored both in Constantinople and in Belgrade (where he opened a consulate) to what extent a federation of South Slav peoples, with Hungary in a leading position, could be implemented (Tamborra 1950; Tommaseo [1840] 1943, pp. 85-107).

In this intricate network of contacts and alternative political designs of potential federations, once again Kossuth suggested that Serbian Prince Mihailo Obrenović should take the lead in forming a union between Serbia, Bulgaria, Montenegro and Bosnia. Meanwhile, Bulgarian revolutionaries like Georgi Sava Rakovski and Ljuben Karavelov actively encouraged Belgrade and Bucharest to take the initiative that would pave the way for Bulgarian independence.

Meanwhile, in 1862, a Serbian intellectual from Vojvodina, Mihailo Polit-Desančić, elaborated a very sophisticated plan for a Balkan federation. He firmly believed that, otherwise, the power politics of the great empires would be able to regularly threaten the partition of South East Europe. By contrast, he assumed that the Balkans had to be protected as an indivisible space, or else Europe as a whole would burst into flames. Therefore, he suggested a very modern regional union with different 
degrees of integration. According to his view, Serbia and Bulgaria would represent the core of a federation with a common Parliament, while Romanians, Greeks, Croatians and other Southern Slav peoples would join the Union in a confederation. A specific autonomous status would be guaranteed to Albanians, Bosniaks and Turks, while Thessaloniki and Carigrad (or Constantinople) would be declared free cities. The capital of the Union would be established in Prizren, where the headquarters of the Balkan Parliament would also be located.

In summary, the powerful ideals of national freedom and stimuli to action developed across Europe through secret societies, illegal movements and revolutionary undertakings where nationalist goals mixed with broader transnational projects, federal ideas and passionate expectations. The ideas did not always include equal rights for all of the "suppressed peoples", who expected to achieve liberty. In most cases, the revolutionary projects ambiguously, or sometimes even explicitly, attributed a leading role to one nation, therefore minimizing the principle of "equality among nations". This was the case when Poland, Hungary or Italy were alternately identified as the most important nations in their macroregional environment, indirectly suggesting a ranking of the nations. The negative reaction to this ranking had far-reaching consequences, especially after the $1870 \mathrm{~s}$.

Actually, conflicting approaches to nationhood and state building began to intensify among activists and leaders of the "suppressed peoples". Their conspiracy strategies frequently diverged ideologically, both in terms of methods and ultimate goals to be achieved.

After the 1860s, some of them believed that it was time to rely on the leadership of small states to embrace and incorporate nationally-asserted territories under foreign occupation. They sought to follow the successful examples of Piedmont and Prussia, which had inflamed the imaginations of generations of revolutionary activists. Inspired by these events, they anxiously nurtured the firm belief, or better the illusion, that similar projects aimed to dismantle Vienna's settlement and establish a "Europe of the peoples" could be achieved completely and quickly (Stipčević 1979).

By contrast, this approach dramatically undermined the complex reality of the time. The interests of ministries and governments (including of the existing and ambitious small states) were often more attuned to territorial expansion than to a revolutionary ethos. While states accepted the leadership of a "liberation movement", nationalizing their foreign and domestic policies accordingly, their governments were facing unpredictable implications, stemming from the alteration of the geopolitical balance at the regional and/or European level. The state apprehensions grew also in relation to the social impact of the domestic and international revolutionary activism. Consequently, conservative elites tried to carefully control the 
potential changes under way. They rejected either instigated or unintended radical claims, such as the distribution of land to the peasantry (to the detriment of landowners), or cautiously guided certain reforms, as, for instance, the gradual introduction of suffrage.

This behavior blatantly marked the policy of the royal houses of Piedmont and Prussia. They successfully established two unexpected political realities in only a few decades, by uniting Italy and the German Reich, respectively, under their own military and political conditions. In both cases, the prime ministers energetically opposed either peasant claims (in Southern Italy) or socialist ideas (in Germany). Even when Otto von Bismarck introduced male suffrage, his bureaucratic administration remained powerfully under the control of the nobles (the Junker, that is the large Prussian landowners). For all of these reasons, they represented a convincing source of inspiration for other "small independent states" or ambitious territories, such as Serbia, the Romanian Regat (Kingdom) after the union of the principalities of Moldavia and Wallachia in 1862 or, later, the Principality of Bulgaria and the Kingdom of Greece after 1863. Ultimately, they also drew the attention of Austrian Galicia toward Ukraine (Magocsi 2002).

At the end of the day, the simultaneous development of multiple and contradictory understandings about freedom, the rights of individuals and collectives, and state organization and its functionality epitomized the configuration that empowered nationalism had inspired equivocally since the nineteenth century. The transformative nature of nationalism depended on many factors. The original aspiration for "freedom for all peoples" against the Vienna restoration was, in reality, reshaped into a divisive, power politics ideology. Governments came to understand how beneficial it was to promote and even manipulate the idea of the nation as a form of power legitimacy and a means for mobilizing consensus. But beyond the nationalist trajectory from a revolutionary ideal, politically in opposition, to an elevated state ideology applied by governmental cabinets according to their views, other aspects contributed to increasing its equivocal content. This was so, since the relations with language, blood, territory and historical experiences were viewed under different, sometimes even opposing, lenses by the activists who claimed to be "nationalists".

Tangible examples are offered by the Polish-Lithuanian and the Croatian-Serbian cases during the eighteenth/nineteenth century concerning their "nation" and future plans for independence.

Despite the evident diversity between the Polish and Lithuanian languages and cultural traditions, the process that led to their demarcation developed slowly because the mutual boundaries remained undefined for centuries. Indeed, since 1547, books in Lithuanian were published 
in Eastern Prussia and then in Königsberg. Furthermore, although the anti-Lutheranism reaction was severe in the whole Commonwealth, the Lithuanians benefited as the religious books were published in the vernacular, and Lithuanian culture was stimulated by the Jesuits in Vilnius.

Indeed, literacy among the peasants, who spoke very different Lithuanian dialects, was a sporadic phenomenon for a long time. The predominant role of the Polish Catholic Church after the Lublin Union (which prevented a direct relation of the Lithuanian lands with the Papacy in Rome) and the unequal relations between the two components of the Commonwealth fostered a polonization of the Lithuanian aristocracy, who normally spoke Polish or Latin.

Under these circumstances, it is not surprising that great personalities of the Polish-Lithuanian cultural environment preserved a double (sometimes even a triple) name and surname: Adam Bernard Mickiewicz or Adomas Bernardas Mickevičius (or Адам Берна́рд Міцке́віч in Belarusian), Adam Jerzy Czartoryski or Adomas Jurgis Čartoriskis, Czeslaw Milosz or Česlovas Milošas (or Чэслаў Мі́лаш) are just a few powerful examples that emblematically confirm how the identity boundaries between the Polish, Lithuanian and sometimes even Belarusian nationhood fluctuated for a long time (Aleksandravičius 2016, pp.57-67). Even General Józef Piłsudski, who belonged to the polonized Lithuanian aristocracy, had a Lithuanian name and a surname: Juozas Pilsudskis (in fact, he was born in the family manor called Zułów close to the Zułowo or Zalavas village in the vicinity of Vilnius/Wilno). This erratic, multiple identity explains well the cultural and political reasons that were behind his Promethean project ${ }^{6}$ to restore the Polish-Lithuanian Commonwealth on the basis of a joint nationhood, to be possibly extended to Belarusians and Ukrainians.

Still, it would be hasty to conclude that this project contemplated inclusiveness of the different ethnic groups on the basis of equal treatment. In fact, the predominant role of the Poles was regularly advocated in different federal projects including Piłsudski himself.

By contrast, alternative processes in ethno-national identity constructions were simultaneously nurtured, or simply developed according to peculiar itineraries, as occurred in the Polish-Lithuanian lands after the failure of the 1830 uprising. As is well known, this event provoked, among other things, the suppression of the University of Vilnius, the abrogation of the Constitution, and a large emigration of the aristocracy and the gentry. They mainly moved to France, where the ideal of the Polish restoration was promoted in literature, music and by conspiracy. We mentioned

6 About the Promethean project see more extensively Chapter 4, at p. 88. 
above, in particular, the activity of Adam Czartoryski. Later, when the revolution erupted in 1848-49, only the Polish territories under Prussia and the Austrian Empire were affected. Furthermore, for the time being, the lack of small independent states in this area of Europe, like Piedmont in Italy, could not play any attractive role (although a Polish military academy was established in Cuneo after the battle of Solferino in 1859!).

After the double defeats of Russia in the Crimea in 1856 and Austria in Lombardy in 1859, protests against military conscription intensified in Vilnius, Kaunas and Grodno, mobilizing Lithuanian, Polish and Belarus youth groups in the tsarist Empire. A state of emergency was imposed, but the situation remained tense, until the protests exploded again in the Kingdom of Poland in 1863. The protests rapidly expanded into some Russian governorates (guberniya) of Lithuania, Ukraine and Belarus, galvanizing mainly the nobles (the szlachta) and the Catholic peasant population. Nevertheless, unable to attract the expected foreign support (mainly from France and the United Kingdom) as well as the active involvement of the peasants, the insurgency was finally crushed.

As a result, the Kingdom of Poland, founded in 1815, was abolished, and its separate status revoked. The Polish lands were incorporated into the western regions of the Russian Empire. Furthermore, a large part of the landlord estates were confiscated with the clear goal of weakening the szlachta. By contrast, as serfdom was abolished in that period, some peasants paid a redemption market price for land or even received land without payment.

In so doing, tsarist Russia applied a strategy aimed at rewarding the loyalty of the peasantry, punishing the nobles, and trying to dissolve the seductiveness of national claims with social reforms. Once concretely implemented on the ground, this strategy increased the economic autonomy of the peasantry (mostly Lithuanian or Belarusian) from the Polish landowners, distinguishing the Lithuanian from the Polish identity. As a result, paradoxically, the tsarist policy reinforced the "detachment" of the Lithuanian identity from the Polish one.

Previously, in reality, romanticism and Herder's influence had played a crucial role in promoting among Lithuanian intellectuals (as in many other regions, including the Balkans, as we will see) the study of folklore, custom, oral poetry, history and language. Nevertheless, tsarist rule was influential in enhancing a process of differentiation that benefited later despite the Russification policy. In fact, the cultural and religious resistance that Russification generated among Lithuanians by imposing the Cyrillic alphabet was primarily determined by the belief of the Catholic population that the introduction of the new alphabet was the first step in converting them to Orthodoxy. As a result, religious books and literature 
in the Latin alphabet were illegally imported from abroad and spread throughout the country. Secret schools increased the peasant literacy. Fatefully, these actions contributed to making Lithuanian-ness an irreversible process distinct from Polish-ness.

A similar dynamic was nurtured by Polish nationalists, who claimed their distinctiveness from other nations, including all those within the former GDL. A radical view was particularly developed by Roman Dmowski. He believed deeply in social Darwinism (or, rather, in Herbert Spencer's interpretation of Darwin), that is in the existence of a "natural" competition between "strong and weak states", with the latter unavoidably doomed to subjugation. He also rejected socialist ideas and federal perspectives. Therefore, Dmowski imagined his Poland under these constraints, ascribing the failure of the Commonwealth in the eighteenth century to its policy of national and religious tolerance (La Mantia 2006, pp. 56-60; LokowskiZawadzky 2009, pp. 211-18; Mole 2012, pp. 20-41).

As a result, he suggested avoiding any nostalgic consideration of the premodern dual experience. Instead, he actively promoted the establishment of a modern Polish nation-state, whose ethnic homogenization should be the key. Openly regarding the minorities as a "threat" to the cohesion and integrity of Polish identity, he concluded that they should be assimilated or encouraged to emigrate. In his vision, the process for building a Polish nation was founded on a narrow connection with the Catholic religion, but also with the need to promote a "healthy national egoism", patently inspired by Fichte's ideas, although Dmowski nurtured an anti-German, and later anti-Semitic attitude.

In 1908 Dmowski still believed that the interests of the Poles, in regard to a war between Russia and Germany with Austria-Hungary, was to fight for the unification of Polish territories under the tsar and then to negotiate autonomy with the Russian government in the name of a "Slav reconciliation". As this strategy appeared to be unsuccessful, given the restrictions imposed on the Poles by the Duma and the tsarist administration before World War I, Dmowski accentuated his anti-Semitism, inviting people to boycott Jewish shops. In his view, the Jews were cooperating with the Germans to dismember the Polish nation. For this reason they were to be considered "dangerous enemies" that should have been forced to emigrate from the country. Although he never advocated the use of violence against minorities, he expressed sympathies toward Italian fascism after World War I, becoming a champion of modern exclusivist ethno-nationalism based on the preservation of "cultural purity", homogeneity and anti-feminism.

In short, the gradual divergence between an inclusive nationalism, which assumed some compatibility with the existence of multiple identities, and an exclusive nationalism, which promoted egoism, assimilation policies 
and a mono-ethnic predominance, marked the construction of identities in Europe as a whole. However, in some areas, the process was particularly painful when the boundaries between identities were vague, undetermined and debatable. The Lithuanian-Polish case was one of these, because of the legacy of the Commonwealth. Despite the evident divergence that grew up during the nineteenth century between the two components of the former Union, they had to go through a war before mutually accepting the separation. And their reconciliation is still a delicate issue (Aleksandravičius 2016).

The Serbo-Croatian case is, in many respects, very similar to the previous one. Of course, the separation of these two identities had to go through two wars (instead of one) and a huge amount of violence, including ethnic cleansing, war crimes and genocide. Many still have not realized the full implications of these events.

Beyond that, if we concentrate on the process of national identity construction, most probably the major difference between the two cases is related to the fact that the ethno-national boundaries remained undefined for a much longer time in the Serbo-Croatian cultural area than in the Polish-Lithuanian relationship. The uncertainties were not only related to what differentiates the Croatian-ness from Serbian-ness, but also to what overlaps in these identities. There was, even, the question of what the relation of these two identities was with Bosnia-Herzegovina and, broadly speaking, with the Yugoslav identity. Partisans of all of these approaches and ways of conduct crucially marked the identity construction of the South Slavs since the eighteenth century through parallel, but then conflicting, processes.

The fluctuation of identities appeared in Dalmatia from the thirteenth to the eighteenth centuries under the patrician republics of Venice and Dubrovnik. Similar to the Polish-Lithuanian Commonwealth, prominent local authors and scholars of sciences often had a double name and surname, like Marko Marulić or Marco Marulo, Ivan Gundulić or Giovanni Gondola, Mavro Orbin or Mauro Orbini, Ruđer Bošković or Ruggero Boscovich. Even in literary classics, as well as the theater, the language was frequently a mixture of Italian and Slavic vernaculars.

However, literacy was limited, especially in the countryside, while the Croatian aristocracy in Slavonia and Croatia proper was mostly under Hungarian cultural influence. They were, therefore, substantially "Magyarized" (similarly to the "Polonized" Lithuanian nobles). In Dalmatia, the local aristocracy was integrated into the Serenissima, while the Serbian nobles de facto vanished, being assimilated into the Ottoman military hierarchy.

It was, then, during the eighteenth century that, as in many other areas 
of Europe, philosophers, linguists and travelers in the South Slav regions began to absorb the ideas of the Enlightenment and rationalism, mirroring a broader, inclusive, identity perception of their cultural space. The historian Jovan Rajić, for example, wrote a history of the Croats, Bulgarians and Serbs, believing that they were to be considered one people. He was not alone in his conviction: the aristocrat Pavao Ritter Vitezović wrote a history book of Croatia (Croatia rediviva, in Latin) in 1700 in which he distinguished two Croatias, the white and the red. The former included current Slovenia, Croatia and Bosnia-Herzegovina, while the latter included Serbia, Macedonia and Bulgaria. Much later, under the influence of romanticism, some intellectuals envisioned the possibility of breeding a common language from the Slovenian to the Bulgarian regions. To that end, a joint alphabet with Latin and Cyrillic letters was created by the Slovenian Jansenist Fran Metelko in 1825, with the support of the conservative leader Juraj Kopitar (Čubrilović 1982; Salvi 1971).

In other words, as we have already stressed, for decades after the 1815 Restoration, the efforts toward national identification were marked by the idea of merging vernaculars for achieving a common standardized language. At the same time, the desire to denote a people with one name (according to the "unification" assumptions) led most of the intellectuals of that time to identify all South Slavs either with the name of Croats or Serbs, generating confusion and later mutual allegations of assimilation and attempted domination.

In the search for identity, in fact, the wealth of diversities within the small peoples of the Balkans offered both an opportunity for federalist/ integrative perspectives, as well as bones of contention for ethno-national separations or hegemonies, in a framework where actual identities fluctuated, fused and re-amalgamated in the passage of time.

As a result, Dositej Obradović, who was a Minister of Education in Serbia and an apologist for the Enlightenment and rationalism, included the Croats in the idea of Serbs. Ritter Vitezovic similarly used the word "Croats" in general terms. Other Serbian authors, like Sava Tekelija, who also had a Hungarian name, Száva Thököly, or the Montenegrin Petar I Petrović Njegoš acted accordingly. In the latter case Montenegro was designated as the core of the future Serbian State, including Dubrovnik, where a Serb-Catholic movement was promoted by distinguished intellectuals like Matija Ban or Medo Pucić/Orsatto Pozza.

The fluidity of all of these ideas gradually generated antithetical visions.

Initially, under the influence of Napoleon and as a reaction against the Restoration, a powerful nationalist mainstream began to develop primarily in the Habsburg Empire, while a suzerain Serbia began to consolidate after the revolutionary period of 1804-15. Attracted by the idea of Illyrism, 
later called Yugoslavism, this movement actively supported the literary agreement achieved in Vienna in 1850 when Serbian and Croatian writers standardized their common language. The agreement was stimulated by the Serb Vuk Karadžić and the Croat (with German origin) Ljudevit Gaj (also called Ludwig Gay).

This language negotiation aimed to identify a common dialect for both Serbs and Croats, in consideration of the fact that the latter, in particular, were speaking a variety of vernaculars. In the end, they decided to use štokavian, which is shared to a large extent by both, despite some minor differences. As a result, the achieved agreement, paradoxically, helped the Croats, in particular, to consolidate their language, while the Yugoslav aspirations developed in the Balkans across the borders of the Austrian and Ottoman Empires. Within this framework, a number of intellectuals from both Croatia and Serbia devoted their lives and energies to support federal, unitarian, inclusive national projects for the South Slav peoples. Such luminaries included on the Croatian side the bishop of Đakovo Josip Juraj Strossmayer, the writer Imbro Tkalac and later the politicians Ante Trumbić and Frano Supilo and the famous sculptor Ivan Meštrović. Serbian proponents included the leader of Serbs in Croatia, Svetozar Pribičević, the mayor of Novi Sad Svetozar Miletić, his close collaborator Mihailo Polit-Desančić, and the socialists Svetozar Marković and Dimitrije Tucović.

Others, however, perceived this unification process as a way to establish a Serbian or, alternatively, Croatian hegemony. Rejecting unification, they sometimes advocated a sharp distinction between the two peoples; at other times, they advocated an "assimilated identification", despite religious belonging. As a result, the ambivalence in the use of the names of the nations lasted for a long time, leading often to mutual resentments and, later, to antithetical political projects.

In this context, the Croatian Ante Starčević, who was a subject of the Habsburg Emperor and is currently considered the "founding father of independent Croatia", denied the existence of the Serbs, Slovenes or Bosniaks as separate nations. Contrary to the Vienna literary agreement, he stated that all of the South Slav peoples were Croats, and the Serbs were simply "Orthodox Croats". Linguistically, he supported another Croatian vernacular, the kajkavian (typical of the region north of Zagreb) with the ekavian accent, which is, paradoxically, similar to the Belgrade accent. Actually, his geopolitical horizon remained circumscribed within the Austro-Hungarian Empire. Therefore, he did not believe in any convergence with other South Slav peoples outside of the borders of the empire. He limited himself to claiming the independence of the Croatian lands from both Vienna and Budapest, considering the Bosnian Muslims fully a 
part of the Croatian "pure culture", while expressing a clear preference for a secularized society.

In supporting his ethno-national and hegemonic view, he also manifested anti-Semitic and racist sentiments - not far, in this sense, from Roman Dmowski's approach (Gross 2000). He believed that most Jews were amoral and, because they were cosmopolitan by culture, they were unable to be loyal to a homeland. In his racist approach, he also elaborated the notion of the "Slavoserbs", which initially was a political category related to his opponents. Later, he applied it to those who did not identify the South Slav process of unification with his idea of Croatian-ness, particularly the Serbs. His ideas were to a large extent propagated by the political party he founded, the Croatian Party of Rights. This party proved to be influential in the following decades. It inspired part of the rightistoriented Croatian political life, including the Ustaša movement after 1929 and, later, the extreme Croatian nationalists at the end of the twentieth century (Bartulin 2014).

Similar hegemonic views, but focusing on Serbian-ness, can be identified in some of the intellectuals mentioned above, from Obradović to Tekelija. However, the geographer Jovan Cvijić believed that the people living in Bosnia-Herzegovina were all Serbian. Vuk Karadžić, too, stated, in some of his works, that all of those who spoke the štokavian dialect were Serbs, following in this a conviction stemming from the teachings of the influential Slovak philologist and ethnographer Pavel Jozef Šafař́k. In Montenegro, Petar II Petrović Njegoš asserted his pro-Serbian orientation particularly in his famous and controversial romantic poem The Mountain Wreath.

In the case of Serbia, however, the centrality of the Serbian ethnos and its prospective hegemonic role in the Balkans was mainly related to its governmental policies. As an independent state already in the nineteenth century, part of its political elite was influenced by the role played by Piedmont in Italy even before 1870. In fact, a reference to it was included in the program of the Radical Party in 1881. It was not by chance that the famous program called Načertanije, inspired by Czartoryski but revised by Ilija Garašanin, was considered by a large part of international literature as the main pan-Serbian geopolitical document, although it remained unknown for decades. It was published for the first time only in 1906, when the inspirational role of Piedmont was gaining a special attractiveness in Belgrade, where the process of democratization was under way and a liberal constitution was enacted. At the same time, the theory and the practice of Giuseppe Mazzini, Tadeusz Kościuszko, Pëtr Kropotkin and Guglielmo Oberdan were still inflaming the imagination and the behavior of secret societies and young generations throughout the Balkans. 
Truly, for a long time Piedmont and its elites dominated the political life of the Kingdom of Italy, particularly to the detriment of the southern regions. However, its success in unifying Italy through a series of annexations, as Prussia also did in the German case, appeared to be a perfect institutional example to be followed in order to achieve a similar goal. Unification, centralization and homogenization appeared, therefore, to be a convincing pathway for building the nation-state following the successful examples, theories and praxis from the nineteenth century.

As a result, the equivocal relation between the reality of annexations and the flourishing of multiple strategies for approaching the national question, under the influence of local dynamics, generated a plurality of antithetical expectations. The transformative and mutant nature of nationalism was enhanced as ideology or, in other words, this ideology showed itself to be flexible enough to be bent to a variety of interpretations.

It is not the aim of this book to reconstruct the history and evolution of the different nationalist mainstream projects. Indeed, the relevant international literature, although often "fragmented", investigating mainly specific national contexts rather than developing a comparative analysis, is vast and solid. What is emphasized here, instead, is that even a comparative reconstruction of two apparently distant cases, like the PolishLithuanian and the Serbo-Croatian, shows the similarities of the multiple nationalist projects that emerged during the nineteenth century and which were doomed to collide. In fact, Lithuanian and Polish separatisms coexisted with Polish hegemonic federalism. Similarly, Yugoslavism developed in coexistence with the pan-Croatian and pan-Serbian projects, right up to the moment when all of them violently settled accounts. Still, these controversial ideals were debated and fostered within circles and cultural mainstreams that aimed to overthrow the existing international order. Thus, they were regularly involved in conspiracies and operated illegally.

At the same time, however, as we previously emphasized, nationalism was increasingly perceived by all of the European governments as a powerful ideology, useful to legitimize state interests. The "Age of Imperialism", triumphantly epitomized by the Congress of Berlin of 1878, dramatically distorted the original revolutionary ethos of the national inspiration for the freedom of peoples and transformed it into a conservative ideology, functional to the expansive policies of the Great Powers.

In other words, when institutionalized, nationalism revealed a great transformative character. But other transformations, in fact, became visible in a variety of political movements. Their programs included contrasting visions and were anticipated by the disputes that crossed the world of the illegal and revolutionary oppositions during the nineteenth century. 
In this trajectory, nationalism abandoned its original libertarian and revolutionary spirit and became a useful policy, consistent with the authoritarian and/or domination goals of the state. This permitted the construction of an ethno-national homogeneity by fostering a historical narrative, a national literature, and a standardized language to be imposed by gradually expanding compulsory public school education and mass military recruitment. Assimilation strategies were also applied against minorities.

Furthermore, the nationalist project fragmented. Instead of promoting the freedom of peoples together with their association, new mainstream movements, mostly inspired by a rigid interpretation of anti-enlightened romanticism, disseminated a narrow-minded idea of it. These movements were based on the protection of a supposed "identity purity" of the group, of "immutable (although invented) traditions", and the rejection of "otherness" as a threat to the preservation of the century-old (if not millennial) "soul" of the nation.

This radicalism was inspired by Herder and Fichte. It was founded on a primordialist idea of the nation, that is, on the eternal "natural" continuity of the nation. The nation, therefore, had a divine genealogy. It nurtured prejudices (giving them a positive connotation), pursued discriminatory policies, and encouraged even violent manifestations of anti-Semitism, which were often integrated into a desire for revenge for real or imagined wrongs suffered in the past from other nations.

The most striking example in this sense was France, after the Sédan defeat and the loss of the regions of Alsace and Lorraine. The anti-German feelings that arose after the 1870 s, paradoxically reversing the same arguments used 70 years earlier by Fichte against France, devastatingly poisoned the relations between the two countries. These feelings radically threatened the national ideals of the Enlightenment and the revolution, and acquired in addition an ardent ethnic and anti-Semitic dimension, as the Dreyfus case of 1894 blatantly corroborated.

It was in this controversial atmosphere that an historian and philosopher, Ernest Rénan, elaborated in 1882 a definition of the nation, which proved to be very influential, but, once again, widely contradictory.

Contrary to the primordial interpretation, he emphasized the role of the "will" of the people to live together as the key component that gives birth to a nation. Accordingly, in his view a nation can dissolve when the collective desire of a group liquefies; therefore, "an everyday plebiscite" is necessary in order to continuously confirm the sense of belonging to a group. This would strengthen the relevance of memory (either in terms of a common remembrance of the past, or of forgetting it) and the joint recognition of a legal framework. His voluntarist interpretation of the nation came close to the constitutional vision of Mazzini. 
However, what was radically different from Mazzini was his antiSemitism, which stemmed from the idea of a hierarchical relation of races that put the Semitic race in a secondary position, inferior to the Aryans. His anti-Semitism was softened, however, by his curious belief that Ashkenazic Jews were originally Turks who converted to Judaism and used Yiddish once they migrated into Central Europe from their collapsed Khazar Khanate. Paradoxically, Rénan was a severe critic of German ethno-nationalism and its anti-Semitism. Actually, he based his racism on the supposed existence of racial differences within humanity. In this sense he mirrored, in essence, a common European bias of the time. The origin of this bias traced back to the spread of the theories of social Darwinism, deeply marking the fusion of nationalism and racism, which had farreaching consequences in the twentieth century.

As a result of these cultural constraints, it was only a few years later that a vibrant reaction against this extremist component of nationalism materialized in the literary world of French society. In 1897 Émile Zola launched a passionate campaign against anti-Semitism and in support of Dreyfus, whose innocence was only recognized in 1908 .

Meanwhile, the increasing animosities that characterized the "Age of Imperialism" further compromised nationalist ideals. The original revolutionary appearances were rapidly transformed into state ideologies, as a source of political legitimization aiming to promote "the supreme interest of the nation" in different contexts. The Great Powers fed into their nationalism the supposed civilizational goals of their colonial policies. Furthermore, a competition between "great" and "small" nationalisms appeared on the horizon, confirmed as a trend by the Balkan Wars at the beginning of the twentieth century. At the same time, the competition among nationalities intensified also within the Great Empires. For the imperial governments, it offered an extraordinary opportunity to apply divide et impera strategies. But it was also a powerful means for directly or indirectly interfering in the internal affairs of other empires (starting with the Sublime Porte), with the aim of weakening them or taking control over part of their territories.

One may reasonably conclude that this was power politics under new circumstances. Nevertheless, this understanding may be relevant to only a part of the dynamics that were roiling European societies. In fact, the plurality of networks of feelings, behaviors and projects inspired by the liberal and democratic revolutionary relations of the nineteenth century was still motivating new generations of insurgents. The education of students, in particular, was broadened by their studies and vivid discussions on social problems related to the peasantry, the working class, the role of capitalism, gender relations, the general suffrage, social-democratic and anarchic ideas, and so on. 
Once again, the intensification of cross-border contacts deeply marked the events at the turn of the century, preparing a fertile ground and a solid "cultural background" for new, epochal, geopolitical transformations. The young revolutionaries were eager to make a new reality, while the Great Powers were still developing their own expansion plans and alliance strategies, firmly believing they had full control of the situation.

In the end, the twentieth century dawned on an altered European Continent. The "solid bodies" of the anciens régimes, the structures and rigidities of traditional habits, including the consolidated social links inherited from the previous centuries and rooted in the countryside or based on solid dependences on religions, had gradually, but inexorably, suffered from liquefaction processes during the whole of the nineteenth century.

The implications of this process of regeneration of the patterns of dependency and interactions were unpredictable for the time being, as the process of fusion was ongoing and comprehensive. Therefore, in the decades to come the European societies would face a long and painful process of social and geopolitical re-amalgamation, whose problematic nature depended to a large extent on the growing multiplicity of the links under liquefaction and the different pace of their liquefaction. 
Stefano Bianchini - 9781786436610 Downloaded from PubFactory at 04/26/2023 12:11:42PM via free access 